The Israeli Journal of Aquaculture - Bamidgeh, IJA_71.2020.1200227, 10 pages

CCBY-NC-ND-4.0 • https://doi.org/10.46989/001c.21646

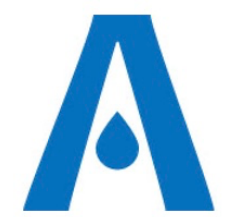

The $I J A$ is a peer-reviewed open-access, electronic journal, freely available without charge to users

Produced by the AquacultureHub non-profit Foundation Sale of IJA papers is strictly forbidden

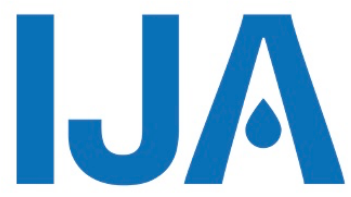

\title{
Effects of Dietary Lipid Levels on Growth Performance, Whole Body Composition and Digestive Enzyme Activity of Juvenile Bighead Carp (Aristichthys nobilis)
}

\author{
Fangfang Cai ${ }^{1}$, Yan Wang ${ }^{1}$, Xianqin Hu ${ }^{1}$, Feng Huang ${ }^{1 *}$, Fucheng Wang ${ }^{2}$, \\ Hongming Liu ${ }^{1}$
}

${ }^{1}$ Key Laboratory for Animal Nutrition and Feed Science of Hubei Province, Wuhan Polytechnic University, Wuhan, China

2Zhanyou Biotechnology Co., Ltd of Hubei Province, Xiaogan China

Key words: lipid level; bighead carp; growth performance; fish body composition; digestive enzyme.

\begin{abstract}
A 60-day study was conducted to investigate the effects of dietary lipid levels on growth, whole body composition and digestive enzyme activity of bighead carp (Aristichthys nobilis) with initial average weight $(3.28 \pm 0.11) \mathrm{g}$. Six isonitrogenous ( $40.25 \%$ crude protein) diets were formulated to contain graded contents of lipid $(4.72 \%, 7.31 \%, 11.02 \%, 14.90 \%, 17.14 \%$, and $19.37 \%$ ) using corn oil and soybean oil as main lipid source. The results showed that the maximum weight gain (WG) and specific growth rate (SGR) were recorded at $11.02 \%$ dietary lipid level. Significant alterations were demonstrated on wholebody composition by different dietary lipid levels. Crude lipid content of whole body increased in parallel with the increase of dietary lipid levels. Fish fed diet with $11.02 \%$ lipid level showed lowest moisture and ash content. The activities of amylase and protease initially increased before decreasing, and the highest activities of amylase and protease were obtained in individuals fed the $11.02 \%$ lipid content diet. There were no significant differences in condition factor (CF) and hepatosomatic index (HSI) $(P>0.05)$. Based on the polynomial regression analysis of WG and SGR, this study suggested that the optimum dietary lipid requirement of juvenile bighead carp was estimated to be $7.77 \% \sim 8.31 \%$.
\end{abstract}

* Corresponding author. Professor Feng Huang, Tel: +86-27-83956175; Fax: +86-2783956175; Email: huangfeng0001@aliyun.com 


\section{Introduction}

Lipid is one of the most important nutrients second only to protein and plays an important role in the optimal use of protein for growth (Cho and Kaushik, 1990). Fish are limited in their ability to use carbohydrates as a source of energy, while lipids are the main source of optimal growth and survival (Krogdahl et al., 2004). In addition to be the major energy source, dietary lipid is also the source of fatty acids necessary for the synthesis of new cell lipids for growth and reproduction, and for the turnover of existing lipids (Halver, 2002).

A large number of researches have been conducted to assess the effects of lipid levels on fish growth. Within a certain range, increasing the level of lipid in the diets has been shown to improve the utilization efficiency of diet and growth performance (Peres and Oliva-Teles, 1999). However, excessive dietary lipid could lead to reduced growth (Meng et al., 2019), excess fat deposition (Chatzifotis et al., 2010) and hepatic steatosis (Gauthier et al., 2007). Therefore, the requirements for the quantification of lipid in feed and their use in farmed fish should be carefully evaluated and determined.

Bighead carp (Aristichthys nobilis), one of the main species of freshwater aquaculture fish in China, is known as the four domestic Chinese carps, together with grass carp, black carp and silver carp. Owing to the short food chain, rapid growth, less disease and low cultivation costs, bighead carp is very suitable for large-scale cultivation, and the total yield of bighead carp has been maintained at about 3 million tons in recent years (in China). The head of bighead carp is highly valuable for cooking and widely used in soup due to its delicious taste and rich collagen (Hong et al., 2013).

The information on the nutrient requirements of bighead carp has been studied in recent years, such as vitamins (Santiago and Gonzal, 2000), phosphorus (Ji et al., 2017), calcium (Liang et al., 2018), protein (Liu et al., 2019) and iron (Feng et al., 2019). The optimal dietary lipid levels for carps have been studied and widely reported by many researchers (Wang et al., 2014; Huang et al., 2019; Wu et al., 2020; etc.). However, no data were available on quantitative requirements of dietary lipid in bighead carp in farmed environment. Therefore, it is urgent to develop the low-cost grower feed and determine the optimal dietary lipid level of bighead carp. Taking that into account, the purpose of this study was to assess the influence of dietary lipid levels on the growth, whole body composition and digestive enzyme activities in juvenile bighead carp. Responses to these parameters were used to deduce an optimum dietary lipid level in this fish, so as to provide scientific reference for the research and development of high-efficiency compound diet for bighead carp.

\section{Materials and Methods}

All feed ingredients were analyzed before use and the data obtained served as the basis for required formulation. Six isonitrogenous diets $(40.25 \%$ crude protein) were prepared with graded lipid levels $(4.72 \%, 7.31 \%, 11.02 \%, 14.90 \%, 17.14 \%$ and $19.37 \%)$. As shown in Table 1, Fish and casein meal were served as protein sources, lipid sources were supplied by soybean oil and corn oil (1: 1 mixture). All ingredients were made into 0.63 $\mathrm{mm}$ size pellet feed, dried at air temperature and then stored at $-20^{\circ} \mathrm{C}$ until future use.

Juvenile $A$. nobilis were taken from a fish farm in Dongxihu District, Hubei Province, China, and domesticated for 30 days before the feeding trial. At the start of the trial, the fish were starving for $24 \mathrm{~h}$. Then, 270 healthy fish with similar size (initial body weight, $3.28 \pm 0.11 \mathrm{~g}$ ) were randomly selected and stocked into eighteen cages (water volume, $300 \mathrm{~L}$; diameter, $80 \mathrm{~cm}$; height, $60 \mathrm{~cm}$ ). 15 fish in each cage were randomly fed six different diets, each group with triplicates. All cages had similar condition. During the experimental period, dissolved oxygen was higher than $6 \mathrm{mg} / \mathrm{L}$, water temperature maintained at about $25^{\circ} \mathrm{C}-28^{\circ} \mathrm{C}, \mathrm{pH} 7.0-7.5$, and the ammonia nitrogen monitored once a week. Fish were fed to apparent satiation by hand three times daily (08:30, 13:00 and 17:30) for 60 days. Uneaten feed and feces have been cleared before feeding.

After starving for $24 \mathrm{~h}$, all fish in each cage were captured for measure and dissection. Body weight, liver weight and body length were measured, respectively. The weight gain (WG; \%), specific growth rate (SGR; \%/day), condition factor (CF) and hepatosomatic index (HSI) were calculated as follows: 
WG $(\%)=100 \times$ (final body weight $(\mathrm{g})$ - initial body weight $(\mathrm{g})$ ) /initial body weight $(\mathrm{g})$ SGR $(\% / d)=100 \times[($ In (final body weight $(\mathrm{g}))-\ln$ (initial body weight $(\mathrm{g}))$ ) / 60 days $]$ CF $\left(\mathrm{g} / \mathrm{cm}^{3}\right)=100 \times$ final body weight $(\mathrm{g}) /$ [body length $\left.(\mathrm{cm})\right]^{3}$

HSI $(\%)=100 \times$ liver weight $(\mathrm{g}) /$ final body weight $(\mathrm{g})$

The fish in each cage were randomly selected for whole body composition analysis (crude lipid, protein, moisture, and ash). The fish whole body moisture was measured by drying in an oven at $105^{\circ} \mathrm{C}$ until the weight was constant. The crude protein contents were measured by the Bradford method (Bradford, 1976). The crude lipid was determined by ether extraction after acid hydrolysis. Ash content was measured after combustion in a muffle furnace at $550^{\circ} \mathrm{C}$ for $5 \mathrm{~h}$.

For the digestive enzymes, the fish were immediately dissected for foregut, hindgut, and liver sampling at ice plate. All samples were homogenized in 10 volumes (w/v) of ice deionized distilled water and centrifuged at $12000 \times \mathrm{rpm}$ for $20 \mathrm{~min}$ at $4{ }^{\circ} \mathrm{C}$. The supernatants were collected for enzyme activity analysis. One unit of amylase activity was defined as $1 \mathrm{mg}$ maltobiose released by starch in $1 \mathrm{~min}$ at $30^{\circ} \mathrm{C}$. One unit of protease activity was defined as $1 \mu \mathrm{g}$ tyrosine released by hydrolysing casein in $1 \mathrm{~min}$ at $30^{\circ} \mathrm{C}$.

All data were expressed as the mean \pm standard error of the mean (mean $\pm \mathrm{SE}$ ). The statistical difference was analyzed by one-way ANOVA and Duncan's multiple comparison test executed in SPSS17.0 software. One-way ANOVA were performed for each sample, and $P<0.05$ was considered as a significant difference.

Table 1 Composition and proximate analyses of the experimental diets ( $100 \mathrm{~g}^{-1}$ of dry matter)

\begin{tabular}{lllllll}
\hline \multirow{2}{*}{$\begin{array}{l}\text { Dietary ingredients } \\
(\%)\end{array}$} & \multicolumn{5}{c}{ Dietary lipid levels (\%) } \\
\cline { 2 - 7 } Casein & $\mathbf{4 . 7 2}$ & $\mathbf{7 . 3 1}$ & $\mathbf{1 1 . 0 2}$ & $\mathbf{1 4 . 9 0}$ & $\mathbf{1 7 . 1 4}$ & $\mathbf{1 9 . 3 7}$ \\
Soybean meal & 35 & 35 & 35 & 35 & 35 & 35 \\
Fish meal & 13 & 13 & 13 & 13 & 13 & 13 \\
Starch & 7 & 7 & 7 & 7 & 7 & 7 \\
Wheat shorts & 18.2 & 18.2 & 18.2 & 18.2 & 18.2 & 18.2 \\
Corn oil & 5 & 5 & 5 & 5 & 5 & 5 \\
Soybean oil & 0 & 1.5 & 3 & 4.5 & 6 & 7.5 \\
Mineral premix & 0 & 1.5 & 3 & 4.5 & 6 & 7.5 \\
Vitamin premix & 3 & 3 & 3 & 3 & 3 & 3 \\
Choline chloride & 1 & 1 & 1 & 1 & 1 & 1 \\
Ca(H2PO4)2 & 0.3 & 0.3 & 0.3 & 0.3 & 0.3 & 0.3 \\
Cellulose & 2.5 & 2.5 & 2.5 & 2.5 & 2.5 & 2.5 \\
\hline Chemical composition & 15 & 12 & 9 & 6 & 3 & 0 \\
\hline Moisture & $100 g^{-1}$ & in dry matter) & & & & \\
Crude lipid & 12.99 & 13.35 & 10.34 & 10.45 & 10.12 & 9.51 \\
Crude protein & 4.72 & 7.31 & 11.02 & 14.90 & 17.14 & 19.37 \\
Crude ash & 39.72 & 39.93 & 40.31 & 40.12 & 40.91 & 40.52 \\
\hline 1Per kilogram & 7.18 & 7.18 & 7.92 & 7.62 & 7.34 & 7.11 \\
\hline
\end{tabular}

${ }^{1}$ Per kilogram of mineral premix containing $\left(\mathrm{g} / \mathrm{kg}\right.$ mixture): $\mathrm{MgSO}_{4} \cdot 7 \mathrm{H}_{2} \mathrm{O}, 745 \mathrm{~g}$; $\mathrm{FeSO}_{4} \cdot \mathrm{H}_{2} \mathrm{O}, 125 \mathrm{~g} ; \mathrm{ZnSO}_{4} \cdot 7 \mathrm{H}_{2} \mathrm{O}, 28.24 \mathrm{~g} ; \mathrm{MnSO}_{4} \cdot 5 \mathrm{H}_{2} \mathrm{O}, 12.96 \mathrm{~g} ; \mathrm{CuSO}_{4} \cdot 5 \mathrm{H}_{2} \mathrm{O}, 2.48$ g; $\mathrm{AlCl}_{3} \cdot 6 \mathrm{H}_{2} \mathrm{O}, 0.8 \mathrm{~g} ; \mathrm{CoCl}_{2} \cdot 6 \mathrm{H}_{2} \mathrm{O}, 0.08 \mathrm{~g} ; \mathrm{KIO}_{3}, 0.24 \mathrm{~g}$; starch, $85.2 \mathrm{~g}$.

2Per kilogram of vitamin premix containing: vitamin A, 700,000 IU; vitamin D3, 350,000 IU; vitamin K, $3.5 \mathrm{~g}$; vitamin E, $16 \mathrm{~g}$; vitamin B1, $3.5 \mathrm{~g}$; vitamin B2, $7 \mathrm{~g}$; vitamin B6, $7 \mathrm{~g}$; vitamin B12, $0.007 \mathrm{~g}$; biotin, $0.03 \mathrm{~g}$; folic acid, $1.6 \mathrm{~g}$; niacin, $35 \mathrm{~g}$; Ca-D-pantothenate, $16 \mathrm{~g}$; inositol, $35 \mathrm{~g}$; vitamin C, $35 \mathrm{~g}$. 


\section{Results}

The results of growth performance of $A$. nobilis fed with different lipid level diets for 60 days were presented in Table 2 . Survival rate (SR) was not significantly affected by dietary lipid level. WG and SGR were significantly affected by the dietary lipid levels $(P<0.05)$. The final weight, WG and SGR reached the maximum value in $11.02 \%$ lipid level group, which were $10.95 \mathrm{~g}, 232.49 \%$ and $2.00 \%$, respectively. As dietary lipid increased from $11.02 \%$ to $19.37 \%$, the final weight, WG and SGR of $A$. nobilis were decreased significantly $(P<0.05)$. The quadratic regression equation between WG and dietary lipid level was $y=$ $-1.0586 x^{2}+16.44 x+157.64\left(R^{2}=0.9342\right)$, and the optimum dietary lipid level was determined to be $7.77 \%$ for the maximum WG. The quadratic regression equation between SGR and dietary lipid level was $y=-0.00785 x^{2}+0.13044 x+1.4145\left(R^{2}=0.9553\right)$, and the optimal dietary lipid level was measured to be $8.31 \%$ for the maximum SGR.

At the end of the feeding experiment, the morphometrical parameters including CF and HSI of $A$. nobilis in each group were measured. As shown in Table 2, the CF and HSI were not significantly influenced by dietary lipid levels $(P>0.05)$.

As shown in Table 3, the whole-body composition was affected by dietary lipid levels $(P<0.05)$. The crude lipid content was increased gradually with dietary lipid levels increased from $4.72 \%$ to $17.14 \%$, and when the dietary lipid level was higher than $17.14 \%$, it showed a significant decline. The crude lipid content in $17.14 \%$ dietary lipid group reached the highest level, which was significantly higher than that in $4.72 \%, 7.31 \%, 11.02 \%$ and $19.37 \%$ group $(P<0.05)$, but there was no significant difference with $14.90 \%$ group $(P>0.05)$.

The crude protein content increased as dietary lipid levels increased from $4.72 \%$ to $14.90 \%$, and achieved the highest level in fish fed the $14.90 \%$ diet, which was significantly higher than that in $4.72 \%$ group $(P<0.05)$, but there was no significant difference among other groups $(P>0.05)$.

The moisture and ash contents first decreased and then increased with the increase in dietary lipid, and they reached the lowest amount in $11.02 \%$ lipid group. The ash content in $11.02 \%$ dietary lipid group was significantly lower than that in $7.31 \%, 14.90 \%, 17.14 \%$ and $19.37 \%$ group $(P<0.05)$, and the moisture of fish fed diets with $11.02 \%$ lipid group was significantly lower than that in $7.31 \%$ and $19.37 \%$ group $(P<0.05)$.

The amylase activities in the foregut, hindgut and liver increased with increasing dietary lipid levels up to $11.02 \%$ diet and thereafter decreased (Table 4). The amylase activity in the foregut of the $11.02 \%$ lipid group was significantly higher than that in the other groups $(P<0.05)$. The amylase activity in the hindgut and liver of the $11.02 \%$ lipid group was significantly higher than that of the $19.37 \%$ lipid group $(P<0.05)$, but there was no significant difference with the other four groups $(P>0.05)$.

The protease activity in the foregut and liver was not significantly affected by different dietary lipid levels $(P>0.05)$ (Table 5). However, dietary lipid level had a significant effect on protease activity in the hindgut $(P<0.05)$, that is, with the increase of lipid level, protease activity in the hindgut increased and thereafter decreased, the protease activity of hindgut reached the maximum value in $11.02 \%$ lipid group, which was significantly higher than that of $17.14 \%$ and $19.37 \%$ lipid group $(P<0.05)$. 
Table 2 Growth, Condition factor (CF) and hepatosomatic index (HSI) of A. nobilis fed with experimental diets

\begin{tabular}{llllllll}
\hline Diet & $\begin{array}{l}\text { Initial } \\
\text { weight/g }\end{array}$ & $\begin{array}{l}\text { Final } \\
\text { weight/g }\end{array}$ & WG/\% & $\begin{array}{l}\text { SGR } \\
(\% / d)\end{array}$ & CF/\% & HSI/\% & SR/\% \\
\hline $4.72 \%$ & $3.25 \pm 0.08$ & $10.31 \pm 1.18^{c}$ & $216.34 \pm 33.4^{c}$ & $1.89 \pm 0.19^{c}$ & $1.91 \pm 0.03$ & $2.15 \pm 0.15$ & $100 \pm 0.00$ \\
$7.31 \%$ & $3.34 \pm 0.11$ & $10.21 \pm 0.75 \mathrm{c}$ & $206.02 \pm 4.16 \mathrm{c}$ & $1.86 \pm 0.22 \mathrm{c}$ & $1.95 \pm 0.04$ & $2.06 \pm 0.16$ & $100 \pm 0.00$ \\
$11.02 \%$ & $3.30 \pm 0.06$ & $10.95 \pm 0.29 \mathrm{c}$ & $232.49 \pm 14.97 \mathrm{c}$ & $2.00 \pm 0.08 \mathrm{c}$ & $1.95 \pm 0.03$ & $2.16 \pm 0.10$ & $100 \pm 0.00$ \\
$14.90 \%$ & $3.28 \pm 0.08$ & $8.14 \pm 0.18 \mathrm{~b}$ & $148.93 \pm 9.79 \mathrm{~b}$ & $1.52 \pm 0.07 \mathrm{~b}$ & $2.04 \pm 0.05$ & $2.20 \pm 0.16$ & $100 \pm 0.00$ \\
$17.14 \%$ & $3.27 \pm 0.08$ & $7.63 \pm 0.28 \mathrm{ab}$ & $133.92 \pm 14.45 \mathrm{ab}$ & $1.41 \pm 0.10 \mathrm{~b}$ & $2.00 \pm 0.04$ & $2.21 \pm 0.13$ & $100 \pm 0.00$ \\
$19.37 \%$ & $3.29 \pm 0.08$ & $5.92 \pm 0.10 \mathrm{a}$ & $80.27 \pm 7.16 \mathrm{a}$ & $0.98 \pm 0.06 \mathrm{a}$ & $2.00 \pm 0.06$ & $2.26 \pm 0.11$ & $100 \pm 0.00$ \\
\hline
\end{tabular}

Each parameter is presented as the mean standard error. Superscript letters of data in the same column indicate significant differences $(P<0.05)$.

Table 3 Effect of different dietary lipid levels on whole body composition (wet basis) of $A$. nobilis

\begin{tabular}{lllll}
\hline Diet & Crude protein (\%) & Crude lipid (\%) & Ash (\%) & Moisture (\%) \\
\hline $4.72 \%$ & $56.48 \pm 1.17^{\mathrm{a}}$ & $18.16 \pm 0.50^{\mathrm{a}}$ & $11.16 \pm 0.46^{\mathrm{ab}}$ & $75.49 \pm 0.77^{\mathrm{ab}}$ \\
\hline $7.31 \%$ & $58.09 \pm 1.14^{\mathrm{ab}}$ & $18.94 \pm 0.48^{\mathrm{ab}}$ & $11.81 \pm 0.52^{\mathrm{b}}$ & $76.55 \pm 0.84^{\mathrm{b}}$ \\
$11.02 \%$ & $58.25 \pm 0.82^{\mathrm{ab}}$ & $19.33 \pm 0.23^{\mathrm{ab}}$ & $10.43 \pm 0.23^{\mathrm{a}}$ & $74.22 \pm 0.53^{\mathrm{a}}$ \\
$14.90 \%$ & $60.16 \pm 0.66^{\mathrm{b}}$ & $20.16 \pm 0.63^{\mathrm{bc}}$ & $12.47 \pm 0.44^{\mathrm{bc}}$ & $75.37 \pm 0.76^{\mathrm{ab}}$ \\
$17.14 \%$ & $58.91 \pm 0.89^{\mathrm{ab}}$ & $21.39 \pm 0.32^{\mathrm{c}}$ & $12.47 \pm 0.47^{\mathrm{bc}}$ & $75.87 \pm 0.58^{\mathrm{ab}}$ \\
\hline $19.37 \%$ & $58.14 \pm 0.83^{\mathrm{ab}}$ & $19.40 \pm 0.27^{\mathrm{ab}}$ & $13.25 \pm 0.43^{\mathrm{c}}$ & $76.96 \pm 0.45^{\mathrm{b}}$ \\
\hline
\end{tabular}

Each parameter is presented as the mean standard error. Superscript letters of data in the same column indicate significant differences $(P<0.05)$.

Table 4 Effects of different dietary lipid levels on the amylase activity (mg.maltose/min.g) of $A$. nobilis

\begin{tabular}{llll}
\hline Diet & Foregut & Hindgut & Liver \\
\hline $4.72 \%$ & $0.73 \pm 0.03^{\mathrm{a}}$ & $0.67 \pm 0.06^{\mathrm{ab}}$ & $0.46 \pm 0.01^{\mathrm{ab}}$ \\
$7.31 \%$ & $0.77 \pm 0.01^{\mathrm{a}}$ & $0.72 \pm 0.01^{\mathrm{ab}}$ & $0.46 \pm 0.01^{\mathrm{ab}}$ \\
$11.02 \%$ & $0.95 \pm 0.10^{\mathrm{b}}$ & $0.75 \pm 0.01^{\mathrm{b}}$ & $0.47 \pm 0.04^{\mathrm{b}}$ \\
$14.90 \%$ & $0.73 \pm 0.05^{\mathrm{a}}$ & $0.71 \pm 0.05^{\mathrm{ab}}$ & $0.44 \pm 0.03^{\mathrm{ab}}$ \\
$17.14 \%$ & $0.70 \pm 0.03^{\mathrm{a}}$ & $0.69 \pm 0.02^{\mathrm{ab}}$ & $0.43 \pm 0.01^{\mathrm{ab}}$ \\
$19.37 \%$ & $0.66 \pm 0.01^{\mathrm{a}}$ & $0.62 \pm 0.02^{\mathrm{a}}$ & $0.42 \pm 0.01^{\mathrm{a}}$
\end{tabular}

Each parameter is presented as the mean standard error. Superscript letters of data in the same column indicate significant differences $(P<0.05)$.

The Israeli Journal of Aquaculture - Bamidgeh • IJA.73.2021.1200227 
Cai et al.

Table 5 Effects of different dietary lipid levels on the protease activity $(\mu \mathrm{g} \cdot \mathrm{Ty} / \mathrm{min} \cdot \mathrm{g})$ of $A$. nobilis

\begin{tabular}{|c|c|c|c|}
\hline Diet & Foregut & Hindgut & Liver \\
\hline $4.72 \%$ & $217.54 \pm 52.86$ & $168.13 \pm 18.10^{b c}$ & $38.80 \pm 5.18$ \\
\hline $7.31 \%$ & $221.68 \pm 13.99$ & $170.69 \pm 4.00^{\mathrm{bc}}$ & $41.90 \pm 1.76$ \\
\hline $11.02 \%$ & $226.87 \pm 32.30$ & $187.48 \pm 13.22^{c}$ & $42.84 \pm 2.54$ \\
\hline $14.90 \%$ & $180.45 \pm 22.92$ & $136.91 \pm 6.86^{\mathrm{abc}}$ & $39.85 \pm 4.50$ \\
\hline $17.14 \%$ & $160.34 \pm 28.86$ & $125.58 \pm 16.14^{\mathrm{ab}}$ & $37.23 \pm 0.78$ \\
\hline $19.37 \%$ & $139.02 \pm 13.12$ & $111.95 \pm 13.50^{\mathrm{a}}$ & $36.45 \pm 2.03$ \\
\hline
\end{tabular}

\section{Discussion}

Lipids in diets not only provides source of energy and essential fatty acids for fish growth, but also acts as solvent for fat-soluble vitamins (Halver, 2002). Suitable dietary lipid is beneficial to promote fish growth, while low or high dietary lipid is not conducive to the growth and development of fish. It is obvious that the best growth performance of $A$. nobilis was obtained in the $11.02 \%$ lipid group, and the decrease in growth with increasing dietary lipid above this level was observed in this study $(P<0.05)$. Moreover, the WG and SGR decreased significantly in $A$. nobilis fed higher lipid diets (14.90\%-19.37\%), indicating that excessive dietary lipid levels lead to obvious growth depression. These findings are consistent with the earlier workers in Puntius gonionotus (Mohanta et al., 2008) and Carassius auratus (Wang et al., 2014). The decrease in growth at high lipid level may attributed to reduced ability to digest and absorb high lipid, reduced feed intake or imbalance of fatty acids in feed (Han et al., 2014).

According to the research of Xiang et al. (2009), the best growth performance of Erythroculter ilishaeformis was found in the lipid diets from $7.88 \%$ to $9.18 \%$. In this study, based on WG and SGR, the largest increases of $A$. nobilis were at dietary lipid levels of $7.77 \%-8.31 \%$. This was in accordance with previous report, and also close to the optimum lipid requirement of Gymnocypris przewalskii (7.35\%) (Meng et al., 2017) and Elopichthys bambusa (7.71\%) (Zhao et al., 2012). However, it is higher than Megalobrama amblycephala (3.6\%, Liu et al., 1992) and lower than Cyprinus carpio (18\%, Corraze, 2001). Different fish species have different dietary lipid requirements, which may be related to dietary formulation, growth stage, and environment conditions. In addition, the fish at different growth stage have different dietary lipid requirement, the best growth for bighead carp fry $(0.0485 \pm 3.5 \mathrm{~g})$ was at lower dietary lipid level $(4.26 \%)$, and the increase in dietary lipid from $4.62 \%$ to $6.95 \%$ depressed growth (Trono-Legiralde, 1996), this finding is inconsistent with our present study.

There are many studies on the influence of dietary lipid levels on fish body composition, but few on the nutrient composition of $A$. nobilis. Reports have shown that high lipid level 
in diets can increase the crude lipid content of fish body, and excessive fat will be deposited in the abdominal cavity and muscle tissue of fish body (Peres and Oliva-Teles, 1999). In this experiment, compared with $4.72 \%$ and $7.31 \%$ lipid levels, fish fed with $11.02 \%$ to $17.14 \%$ lipid level diets showed higher crude lipid contents, indicating that with the increase of dietary lipid level, the lipid deposition in the fish body may be enhanced. The result was accordant with that in cobia (Rachycentron canadum; Wang et al., 2005) and grass carp (Ctenophryngodon idella; Köprücü, 2012). Thus, for different species of fish, an increase in dietary lipid levels should be carefully assessed, as this may result in excessive fat deposition in fish.

The decrease in crude protein and moisture content were observed with Epinephelus bruneus fed higher dietary lipid levels (Kakuta et al., 2010), which was also reported in Carassius auratus (Wang et al., 2014). However, in the present study, the protein content of the juveniles increased with the increasing dietary lipid level up to $14.90 \%$, and thereafter showed a downward trend. The variation trend of moisture content was completely opposite to that of protein content, and as dietary lipid level reached $11.02 \%$, the moisture content of bighead carp was the lowest $(P<0.05)$. These results of this study differed from those reported above, possibly due to differences in fish species, dietary lipid level, lipid source and season, and the related mechanisms should be further discussed in future studies.

HSI is an indication of the body condition of the fish, HSI values in the present study were not significantly influenced by the dietary lipid levels. No differences in the HSI were found in other species due to changes in dietary lipid level (González-Félix et al., 2015; Yuan et al., 2016). CF is an important tool of measuring body shape and a good indicator of reflecting dietary condition (Grigorakis, 2007). There were no significant differences among the six dietary lipid groups in CF, which showed a slight upward and then downward trend in the process of the experiments. Inconsistent with the results of this study, some researchers found that CF value decreased with the increase of dietary lipid level (Chatzifotis et al., 2010). The result of the present study was not consistent with previous studies, suggesting that the differences between these researches may be due to the differences in dietary structure and lipid source.

The growth process involves many factors, among which the digestion and absorption of organisms are strongly influenced. Digestive enzymes are vital substances that maintain the normal metabolism of the body, the activity of fish digestive enzymes is the response of fish body to the digestibility of nutrients (Hidalgo et al., 1999). There are many studies on the effect of dietary lipid levels on fish digestive enzyme activity, however, due to the type of fish, eating patterns, growth stages and experimental conditions, the results were quite different (Mohanta et al., 2008; Wu et al., 2020). In the present study, amylase activities in the foregut, hindgut and liver represented a trend of first increase and then decrease with the increase of dietary lipid. Fish fed $11.02 \%$ lipid diet revealed the highest amylase activities, and as the level of dietary lipid was higher than $11.02 \%$, the activities of amylase decreased gradually. According to the research of Wu et al. (2020), the amylase activities could be significantly increased, digestibility and utilization of diet could be promoted in Ctenopharyngodon idellus fed diets with lipid level from $4 \%$ to $8 \%$, and higher lipid diet can reduce the amylase activities. The above report is basically consistent with our present results. However, the highest amylase activity of Myxocyprinus asiaticus was found in low lipid level group (2.04\%), as dietary lipid level increased, intestinal amylase activity first decreased and then stabilized (Wang et al., 2010). That might be due to the difference in fish species, eating patterns, growth phase and so on. The mechanism between the activity of amylase and the dietary lipid is uncertain, but further research should be needed to uncover this.

It was found that protease activity was directly related to the growth rate of carp (Hidalgo et al., 1999). The maximum WG in $11.02 \%$ lipid group was probably due to highest protease activity under this lipid level. However, when the lipid level was higher than $11.02 \%$, the protease activities were gradually decreased, indicating that high-lipid level may inhibit protease activity. Similar result was also reported in other study, in which high lipid level lead to low activity of protease (Mohanta et al., 2008). The above results 
suggested that $11.02 \%$ lipid level group might improve the secretion and activity of digestive enzymes, and facilitate the digestion and absorption of feed in bighead carp.

In conclusion, the results of this study demonstrated that the maximum WG and SGR, the highest digestive enzyme activity, and the lowest value of moisture and ash content were all recorded at $11.02 \%$ dietary lipid level. Based on the WG and SGR, the optimum dietary lipid level of this species was determined to be $7.77 \%-8.31 \%$. To our knowledge, this is the first report to date on the optimal dietary lipid levels of juveniles bighead carp, and these data should be helpful in compound diet development for this fish species.

\section{Acknowledgements}

This research was financially supported by Fujian Province Key Laboratory of Special Aquatic Formula Feed (Fujian Tianma Science and Technology Group Co., Ltd.). Part work were done in Freshwater Aquaculture Collaborative Innovation Center of Hubei Province, Wuhan, China.

Chatzifotis S., Panagiotidou M., Papaioannou N., Pavlidis M., Nengas I. and Mylonas C. C., 2010. Effect of dietary lipid levels on growth, feed utilization, body composition and serum metabolites of meagre (Argyrosomus regius) juveniles. Aquaculture, 307(1-2), 65-70. 10.1016/j.aquaculture.2010.07.002

Cho C. Y. and Kaushik S. J., 1990. Nutritional energetics in fish: energy and protein utilization in rainbow trout (Salmo gairdneri). World Rev Nutr Diet, 61, 132-172. $10.1159 / 000417529$

Corraze G., 2001. Lipid nutrition. In: Guillaume, J., Kaushik, S., Bergot, P., Métailler, R. (Eds.), Nutrition and Feeding of Fish and Crustaceans. Springer-Praxis Books, Chichester, UK, pp. 111-130.

Feng W., Hu X., Wang F., Huang F., Liu L., Li H., Liu H., Yang W., 2019. Effect of dietary iron levels on growth, iron concentration in tissues, and blood concentration levels of transferrin and hepcidin in bighead carp (Aristichthys nobilis). Aquacult Res, 00, 1-7.

10.1111/are.14457

Gauthier M. S., Favier R. and Lavoie J. M., 2007. Time course of the development of non-alcoholic hepatic steatosis in response to high-fat diet-induced obesity in rats. Brit $J$ Nutr, 95, 273-281. 10.1079/BJN20051635

González-Félix M. L., Minjarez-Osorio C. M., Perez-Velazquez, Urquidez-Bejarano P., 2015. Influence of dietary lipid on growth performance and body composition of the Gulf corvina, Cynoscion othonopterus. Aquaculture, 448, 401-409. $10.1016 /$ j.aquaculture.2015.06.031

Grigorakis K., 2007. Compositional and organoleptic quality of fanned and wild gilthead sea bream (Sparus aurata) and sea bass (Dicentrarchus labrax) and factors affecting it: A review. Aquaculture, 272(1-4), 55-75. 10.1016/j.aquaculture.2007.04.062

Halver J. E., 2002. In: Fish Nutrition $3^{\text {rd }}$ edition. pp. 62-141. Edited by Halver, J. E. and Hardy, R. W. Academic Press, San Diego. https://doi.org/10.1016/B978-0-12-3196521.X5000-9

Han T., Li X., Wang J., Hu S., Jiang Y. and Zhong X., 2014. Effect of dietary lipid level on growth, feed utilization and body composition of juvenile giant croaker Nibea japonica. Aquaculture, 434, 145-150. 10.1016/j.aquaculture.2014.08.012

Hidalgo M. C., Urea E. and Sanz A., 1999. Comparative study of digestive enzymes in fish with different nutritional habits. Proteolytic and amylase activities. Aquaculture, 170, 267-283. 10.1016/S0044-8486(98)00413-X

Hong H., Luo Y., Zhou Z., Bao Y., Lu H. and Shen H., 2013. Effects of different freezing treatments on the biogenic amine and quality changes of bighead carp (Aristichthys nobilis) heads during ice storage. Food Chem, 138(2-3), 1476-1482. 10.1016/j.foodchem.2012.11.031

Huang C., Sun J., Ji H., Oku H., Chang Z., Tian J., Yu E. M., Xie J., 2019. Influence of dietary alpha-lipoic acid and lipid level on the growth performance, food intake and gene expression of peripheral appetite regulating factors in juvenile grass carp 
(Ctenopharyngodon idellus). Aquaculture, 505 (30), 412-422. https://doi.org/10.1016/j.aquaculture.2019.02.054

Ji K., Liang H., Mi H., Mokrani A., Xie J., Liu B., Ge X., Ren M., 2017. Effects of Dietary Phosphorus Levels on Growth Performance, Plasma Biochemical Parameters, and Relative Gene Expression of Lipogenesis of Bighead Carp, Aristichthys nobilis. Bamidgeh, 1451, 19.

Kakuta Y., Fumiaki T., Hung P. N., 2010. Effect of dietary lipid level on growth performance and feed utilization of juvenile kelp grouper Epinephelus bruneus. Fish Sci, 76, 139-145. 10.1007/s12562-009-0191-0

Köprücü K., 2012. Effects of dietary protein and lipid levels on growth, feed utilization and body composition of juvenile grass carp (Ctenopharyngodon idella). Journal of Fisheriessciences.com, 6(3), 243-251. 10.3153/jfscom. 2012028

KrogdahI A., Hemre G. I. and Mommsen T. P., 2004. Carbohydrates in fish nutrition: digestion and absorption in postlarval stages. Aquacult Nutr, 11(2), pp.103-122. 10.1111/j.1365-2095.2004.00327.x

Liang H., Mi H., Ji K., Ge X., Ren M., Xie J., 2018. Effects of dietary calcium levels on growth performance, blood biochemistry and whole-body composition in juvenile bighead carp (Aristichthys nobilis). Turk J Fish Aquat Sc, 18, 623-631. 10.4194/1303-2712v18_4_14

Liu M. Z., Shi W. L., Zhu C. W., Lu M. Y., Wang G. L. and Wang F. Q., 1992. The effect of dietary lipid level on the growth of blunt snout bream (Megalobrama amblycephala) fingerling. Journal of Fisheries of China, 16(4):330 -336.

Liu L., Wang F., Huang F., Li J., Hu X., Feng W., Wang Y., 2019. Feed processing and protein requirement of bighead carp. Freshwater Fisheries, 49 (6), 75-81.

Meng Y., Li C., Qin Q., Tong Y., Zhu R., Xu G., Shi Y. Shi J., Ma R., 2017. Dietary Lipid Levels Affect the Growth Performance, Lipid Deposition, and Antioxidative Capacity of Juvenile Scaleless Carp, Gymnocypris przewalskii, on the Qinghai-Tibetan Plateau. J World Aquacult Soc, 49(4), 788-797. 10.1111/jwas.12474

Meng Y., Qian K., Ma R., Liu X., Han B., Wu J., Zhang L., Zhan T., Hu X., Tian H., Li C., 2019. Effects of dietary lipid levels on sub-adult triploid rainbow trout (Oncorhynchus mykiss): 1 . Growth performance, digestive ability, health status and expression of growthrelated genes. Aquaculture, 513, 734394. https://doi.org/10.1016/j.aquaculture.2019.734394

Mohanta K. N., Mohanty S. N., Jena J. K. and Sahu N. P., 2008. Optimal dietary lipid level of silver barb, Puntius gonionotus fingerlings in relation to growth, nutrient retention and digestibility, muscle nucleic acid content and digestive enzyme activity. Aquacult Nutr, 14, 350-359. 10.1111/j.1365-2095.2007.00542.x

Peres H. and Oliva-Teles A., 1999. Effect of dietary lipid level on growth performance and feed utilization by European sea bass juvenile (Dicentrarchus labrax). Aquaculture, 179, 325-334. 10.1016/S0044-8486(99)00168-4

Santiago B. C. B. and Gonzal A. C., 2000. Effect of prepared diet and vitamins A, E and C supplementation on the reproductive performance of cage-reared bighead carp Aristichthys nobilis (richardson). J Appl Ichthyol, 16(1), 8-13.

10.1046/j.1439-0426.2000.00137.x

Trono-Legiralde M. T., 1996. Effects of dietary carbohydrate, lipid and energy on the growth, feed efficiency, and tissue composition of bighead carp (Aristichthys nobilis) fry. Fish Nutrition and Feeds '94 Proceedings, 111. http://hdl.handle.net/10862/542

Wang J. T., Liu Y. J., Tian L. X., Mai K. S., Du Z. Y., Wang Y., \& Yang H. J., 2005. Effect of dietary lipid level on growth performance, lipid deposition, hepatic lipogenesis in juvenile cobia (Rachycentron canadum). Aquaculture, 249, 439-447. 10.1016/j.aquaculture.2005.04.038

Wang A., Yang W., Shen Y., Han G., Lv F., Yu Y.... Zhang J., 2014. Effects of dietary lipid levels on growth performance, whole body composition and fatty acid composition of juvenile gibel carp (Carassius auratus gibelio). Aquacult Res, 46(11), 2819-2828. 10.1111/are. 12571 
Wang C., Luo L., Zhang G., Shang W., Jiao S., Cong X., Yan Z., Liu E., 2010. Effects of Dietary Lipid Levels on Growth Performance, Intestinal Digestive Enzyme Activities and Lipid Metabolism of Chinese Sucker (Myxocyprinus asiaticus). Chinese Journal of Animal Nutrition, 22(4), 969-976.

Wu W., Ji H., Yu H., Sun J., Zhou J., 2020. Effect of refeeding dietary containing different protein and lipid levels on growth performance, body composition, digestive enzyme activities and metabolic related gene expression of grass carp (Ctenopharyngodon idellus) after overwinter starvation. Aquaculture, 523. https://doi.org/10.1016/j.aquaculture.2020.735196

Xiang X., Zhou X. H., Chen J., Duan B., 2009. Effects of Dietary Lipid Levels on Growth Performance and Body Composition of Juvenile Erythroculter ilishaeformis. Chinese Journal of Animal Nutrition, 21(3), 411-416.

Yuan X., Liang X. F., Liu L., Fang J., Li J., Li A., Cai W., Xue M., Wang J., Wang Q., 2016. Fat deposition pattern and mechanism in response to dietary lipid levels in grass carp, Ctenopharyngodon idellus. Fish Physiol Biochem, 42(6), 1557-1569. 10.1007/s10695-016-0240-4

Zhao Q., Zhu B., Shen F., Fan Q., Song L., Yang L., Yang W., Sun C., Chen H., 2012. Effect of dietary lipid levels on growth, body composition and blood biochemical indices of juvenile yellow cheek carp (Elopichthys bambusa). Journal of Huazhong Agricultural University, 31(3), 357-363. 